\title{
Implementasi Mail Server Berbasis Squirrelmail Dengan Exchange Server Menggunakan Teknologi Virtualisasi di SMK Negeri 1 Pendalian IV Koto
}

\author{
Basorudin $^{1}$ \\ ${ }^{1}$ Program Studi Teknik Informatika, Fakultas Ilmu Komputer Universitas Pasir Pengaraian \\ Telp.082213224505 Email : basorudin09@gmail.com
}

\begin{abstract}
Server virtualization technology is the use of one physical machine by several server operating systems. The design and implementation of this mail server was built using Debian.5 as the base operating system server. The design and implementation of mail servers is built using the dns server, web server and mail server / squirrelmail, configured using the help of the virtualbox application as a server. DNS (Domain Name System) is a system that stores information about host names and domain names in the form of scattered databases (distributed databases) on a computer network, for example the Internet. The application used to handle the delivery of mail messages is the mail server. This mail server always receives messages from e-mail clients that the user uses, or maybe from other e-mail servers. Web mail functions to send and view e-mail messages through a web browser. The squirrelmail configuration is done by running the conf.pl: $\$$ / var / www / wemail / config / conf.pl script. Exchange Server services include: Directory Service, Simple Mail Transfer Protocol (SMTP), Post Office Protocol (POP3), IMAP (Internet Message Access Protocol), Complementary Services, System Attendants. For Mail Server Delivery Process can be seen in number 5.2.
\end{abstract}

Keyword: Squirrelmail, Exchange Server, DNS Server, Web Server, Mail Server.

Intisari- Teknologi virtualisasi server merupakan penggunaan bersama satu mesin fisikal oleh beberapa sistem operasi server. Perancangan dan implementasi mail server ini dibangun dengan menggunakan Debian.5 sebagai base operating system server. Perancangan dan implementasi mail server ini dibangun dengan menggunakan dns server, web server dan mail server/squirrelmail, di konfigurasi menggunakan bantuan aplikasi virtualbox sebagai server. DNS (Domain Name System) adalah sebuah sistem yang menyimpan informasi tentang nama host maupun nama domain dalam bentuk basis data tersebar (distributed database) di dalam jaringan komputer, misalkan Internet. Aplikasi yang digunakan untuk menangani penghantaran pesan mail adalah mail server. Mail server ini senantiasa menerima pesan dari e-mail client yang digunakan user, atau mungkin dari server e-mail lainnya. Web mail berfungsi untuk mengirim dan melihat pesan email melalui web browser. Konfigurasi squirrelmail dilakukan dengan menjalankan skrip conf.pl : \$/var/www/wemail/config/ conf.pl. Layanan Exchange Server antara lain : Directory Service, Simple Mail Transfer Protocol (SMTP), Post Office Protocol ( POP3 ), IMAP (Internet Message Access Protocol), Complementary Services, System Attendant. Untuk Proses Pengiriman Mail Server dapat dilihat pada nomor 5.2.

Kata Kunci: Squirrelmail, Exchange Server, DNS Server, Web Server, Mail Server.

\section{Pendahuluan}

Kita semua khusunya yang berkecimpung dalam dunia pendidikan pasti pernah menerima dan mengirim e-mail dengan menggunakan internet, maka hal tersebut merupakan salah satu arti dari Mail Server. Dewasa ini bisa dipastikan hampir semua perusahaan, kampus, sekolah, perkantoran dan instansi-instansi lain telah mengadopsi teknologi internet dan mail server. Teknologi internet dan mail server dengan segala kelebihan dan kekurangannya telah dimanfaatkan oleh banyak pihak, ada yang memanfaatkannya untuk hal-hal positif, dan ada pula yang memanfaatkan ke hal-hal yang negatif seperti menyebarkan virus, spam dan lain-lain.

Sebagai sarana penunjang kegiatan di SMK Negeri 1 Pendalian IV Koto aktifitas staff TU, guru dan siswa saat ini masih menggunakan domain gmail, email maupun yahoo yang bersifat publik sehingga tidak merepresentasikan sekolah tersebut. Sebagai sekolah yang memiliki jurusan komputer yaitu jurusan Teknik Komputer Jaringan, sewajarnya SMK Negeri 1 Pendalian IV Koto mengimplementasikan penggunaan email lokal dalam aktivitas keseharian, sehingga pengembangan dari infrastuktur jaringan yang fleksibel dapat dilakukan.

Teknologi virtualisasi server merupakan penggunaan bersama satu mesin fisikal oleh beberapa sistem operasi server. Virtualisasi server bertujuan untuk memudahkan backup dan maintenance sumber daya perangkat keras berupa prosesor dan memori yang dapat dialokasikan sesuai kebutuhan komputasi. (Heru Prasetiawan, 2016).

\section{A. Rumusan Masalah}

Berdasarkan uraian pada latar belakang diatas, dapat dirumuskan suatu permasalahannya yaitu: 
1. Bagaimana membangun mail server berbasis squirrelmail dengan exchange server menggunakan teknologi virtualisasi server?

2. Bagaimana mengimplementasikan mail server sebagai penunjang komunikasi antar guru, staf TU, kepala sekolah dan siswa-siswi di SMK N 1 Pendalian IV Koto?

\section{B. Tujuan Penelitian}

1. Memanfaatkan teknologi virtualisasi sebagai teknologi baru yang mudah digunakan untuk membangun sebuah mail server dengan biaya yang terjangkau.

2. Memanfaatkan mail server untuk berkomunikasi dan mempermudah penyebaran informasi antar guru, staf TU, kepala sekolah dan siswa-siswi di SMK N 1 Pendalian IV Koto.

\section{Ruang Lingkup}

Adapun ruang lingkup dari penelitian ini adalah :

1. Implemntasi dilakukan dengan server non fisik karena adanya keterbatasan sarana prasarana.

2. Mail server dibangun menggunakan domain simulasi atau menggunakan teknonologi Virtualisasi dengan bantuan software VMware atau Virtualboox.

3. Mail server ini hanya dibangun dan diperuntukkan pada ruang lingkup SMK N 1 Pendalian IV Koto.

4. Fitur Exchange Server yang di implementasikan dalam penelitian ini adalah, DNS Server, Web Server dan Mail Server.

\section{Tinjauan Pustaka}

\section{A. Jaringan Komputer}

Jaringan komputer adalah sebuah rangkaian dua atau lebih komputer yang saling terhubung satu sama lain. Komputer-komputer ini akan terhubung dengan sebuah sistem komunikasi (Heru Prasetiawan, 2016). Sebuah jaringan biasanya terdiri dari dua atau lebih komputer yang saling berhubungan diantara satu dengan yang lainnya, dan saling berbagi sumber daya misalnya CDROM, Printer, Pertukaran File, atau memungkinkan untuk saling berkomunikasi secara elektronik. Komputer yang terhubung tersebut dimungkinkan berhubungan dengan media kabel, saluran telepon, gelombang radio, satelit atau infrared. (Muhammad Dedy Haryanto, 2014).

\section{B. Email}

Pesan elektronik atau yang akrab disebut e-mail merupakan istilah untuk pesan/surat elektronik; biasanya berbentuk pesan teks sederhana yang ditulis seseorang (user) melalui sebuah sistem komputer dan ditransmisikan ke komputer lain yang dituju dengan melintasi jaringan internet Saat ini e-mail banyak digunakan karena ekonomis, lebih simpel, sangat cepat, mudah dikelola, dan mampu mentransmisi beragam format dokumen. (Kusmaya, 2016).

\section{Virtualisasi}

Virtualisasi adalah teknologi yang mengizinkan sistem komputer untuk membuat suatu sistem komputer bayangan didalam sistem komputer tersebut. Virtualisasi server adalah penggunaan perangkat lunak yang memungkinkan satu perangkat keras untuk menjalankan beberapa sistem operasi dan services pada saat yang sama, sedangkan virtual server adalah penggunaan perangkat lunak yang memungkinkan banyak perangkat keras untuk menjalankan satu sistem secara terpadu, (Vredi Sanjaya, 2013).

Teknologi virtualisasi merupakan sebuah teknologi yang memungkinkan sebuah mesin fisik dijadikan sebuah sumber daya bersama yang dapat dibagi dan dipakai oleh beberapa layanan sekaligus. Layananlayanan tersebut dapat dikonfigurasikan sendiri tanpa mempengaruhi konfigurasi dari layanan lainnya meskipun dalam satu mesin fisik yang sama. (Budi Harijanto, 2015).

\section{Linux}

Linux Merupakan sistem operasi yang diciptakan oleh Linus Trovalds di bawah lisensi GPL (General Public Licensi). Distro berasal dari kata distribution yang dapat diartikan sebagai penyebaran, jika dikaitkan dengan Linux, maka adalah penyebaran paket Linux. Kelebihan Linux di antaranya, tahan terhadap serangan virus, tidak mudah crash dan hang karena window manager terpisah 
dengan inti dari sistem operasi, mudah didapat dengan harga terjangkau, mempunya lisensi yang sangat moderat, dapat berjalan di beberapa arsitektur komputer 32 bit atau 64 bit, ringan, terutama jika tanpa menggunakan Graphical User Interface (GUI). ( Desmira, 2017).

\section{E. DNS Server}

DNS (Domain Name System) adalah sebuah sistem yang menyimpan informasi tentang nama host maupun nama domain dalam bentuk basis data tersebar (distributed database) di dalam jaringan komputer, misalkan Internet, (Desmira, 2017). DNS memeberikan fasilitas berupa alamat IPAddress untuk setiap nama host (Client) dan mendata setiap server transmisi surat (mail exchange server) yang menerima surat elektronik (email) untuk setiap domainnya.

\section{F. Mail Server}

Aplikasi yang digunakan untuk menangani penghantaran pesan mail adalah mail server. Mail server ini senantiasa menerima pesan dari e-mail client yang digunakan user, atau mungkin dari server e-mail lainnya. Sesuai dengan namanya, server e-mail adalah pusat kendali sistem e-mail. Sebuah mail server biasanya terdiri dari area penyimpanan, set konfigurasi user, daftar user, dan seri modul komunikasi (Kusmaya, 2016).

\section{G. Squirrelmail}

Salah satu paket webmail standar yang ditulis dalam bahasa pemrograman PHP4. Pemrograman PHP nya sudah mendukung protocol POP, IMAP dan SMTP. Instalasi dan konfigurasinya pun tidak terlalu sulit. Berbeda dengan konfigurasi aplikasi lain, SquirrelMail lebih interaktif, sehingga dapat dikonfigurasi sesuai keinginan, (Desmira, 2017).

\section{H. Layanan Exchange Server}

Layanan-layanan dari Exchange server ini sendiri adalah sebagai berikut :

\section{1) Directory Service}

Layanan yang berfungsi mirip dengan direktori telepon dimana nomor telepon seseorang dapat dengan mudah dicari. Jadi jika seseorang mengirim email,
Exchange Server menggunakan Directory Service untuk mencari atribut nama yang dituju agar email tersebut dapat disampaikan dengan baik dan cepat.

\section{2) Simple Mail Transfer Protocol (SMTP)}

Simple Mail Transfer Protocol (SMTP) adalah protokol yang disediakan untuk mengatur pengiriman email lewat Internet.

\section{3) Post Office Protocol (POP3)}

Protokol yang digunakan untuk mengambil surat elektronik (email) dari server email. SMTP berguna untuk mengirim surat elektronik dari komputer pengirim ke server.

\section{4) IMAP (Internet Message Access Protocol)}

IMAP adalah singkatan dari Internet Message Access Protocol, sedangkan POP merupakan singkatan dari Post Office Protocol. Dengan kata lain, keduanya adalah protocol email. Kedua sistem (IMAP dan POP) memungkinkan kamu untuk mengakses email menggunakan software email client, seperti Microsoft Outlook dan Mozilla Thunderbird.

\section{5) Complementary Services}

Fungsi utama komponen ini adalah untuk mendukung kerjasama dengan fasilitas IIS lainnya seperti Network News Transfer Protocol (NNTP), Post Office Protocol version 3 (POP3), Internet Massage Access Protocol version 4 (IMAP4), Outlook Web Accces, Outlook Mobile Access dan Exchange ActiveSync.

\section{6) System Attendant}

System Attendant merupakan komponen Exchange Server yang mengawasi semua fungsi komponen komponen lainnya. Komponen ini berfungsi untuk menjaga kinerja sistem mail Exchange Server dan menjaga agar setiap komponen Exchange Server lainnya dapat menyelesaikan tugas tugasnya dengan baik. (Zainul Hakim, 2015) 


\section{III.Metodologi Penelitian}

\section{A. Diagram Sistem Berjalan}

Layanan email yang digunakan saat ini antar Guru, staf TU, Kepala sekolah dan siswa-siswi di SMK N 1 Pendalian IV Koto masih menggunakan public email (gmail.com dan yahoo.com). Sementara itu penggunaan email publik oleh Guru, staf TU, Kepala sekolah dan siswa-siswi kurang mampu mencerminkan sekolah di SMK N 1 Pendalian IV koto yang notabene memiliki jurusan komputer. Diagram sistem berjalan dapat di lihat seperti gambar 1 .

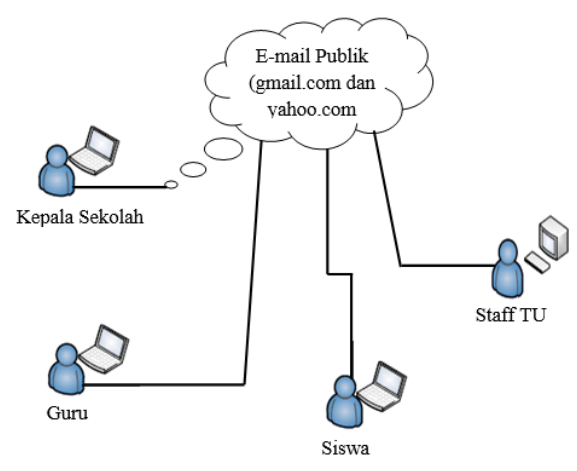

Gambar 1. Penggunaan Email Public

\section{B. Sistem Usulan}

Sistem yang ditawarkan dalam peneltian ini adalah Guru, staf TU, Kepala sekolah dan siswa-siswi melakukan aktifitas komunikasi dan pengiriman file menggunakan email privat/lokal yang telah dibangun dengan satu server yang telah di installkan system operasi linux debian (open source) dan server yang telah di konfigurasi dns, web dan mail server. Sehingga SMK N 1 Pendalian IV koto memiliki kebanggan tersendiri karena mereka mampu memanfaatkan email local yang telah dibangun sendiri, dan mengurangi penggunaan email public yang sudah biasa digunakan pihak lain. System usulan yang ditawarkan dapat dilihat pada gambar 2 .

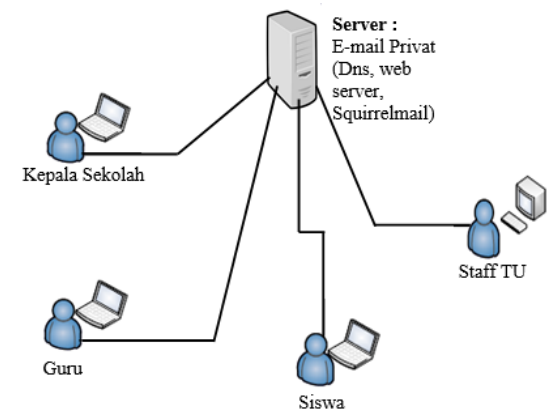

Gambar 2. Sistem usulan mail server

\section{Kebutuhan Perangkat Keras dan Perangkat Lunak}

Perangkat keras dan perangkat lunak yang dibutuhkan untuk system ini adalah sebagai berikut :

1) Perangkat Keras
a. 1 buah Personal Komputer sebagai server
b. Laptop atau PC untuk Client.
c. Hub/Switch

2) Perangkat Lunak

a. Linux Debian sebagai sistem operasi untuk server.

b. IP Address

c. Dns server, web server, mail server

\section{IV.IMPLEMENTASI}

\section{A. DNS Server}

DNS server berfungsi untuk menerjemahkan nama domain ke alamat IP dan sebaliknya. Aplikasi yang digunakan sebagai DNS server adalah BIND9. Instalasi BIND9 dilakukan menggunakan apt-get.

\section{B. Postfix}

Postfix adalah mail server gratis berbasis open source yang dibuat oleh Wietse Venema. (Kusmaya, 2016). Untuk menjalankan Postfix, maka paket Postfix harus diinstall terlebih dahulu ke linux.

\section{Dovecot}

Dovecot digunakan untuk melengkapi Postfix sebagai mail server. Dovecot adalah aplikasi POP3 dan IMAP server yang bertugas untuk meneruskan e-mail dari server ke client. Aplikasi Dovecot di-install melalui terminal yang ada pada linux. (Kusmaya, 2016).

\section{Web Mail dan Squirrelmail}

Web mail berfungsi untuk mengirim dan melihat pesan email melalui web browser, user akan menjadi sulit jika menggunakan telnet yang berbasis command prompt karena tentu saja ini tidak user friendly. Solusinya ntuk memudahkannya maka perlu diinstal squirrelmail sebagai webmail client. Setalah di install kemudian Ekstrak source squirrelmail, ubah nama hasil ekstrak menjadi folder webmail. Lalu pindahkan folder tersebut ke dalam direktori /var/www/. Konfigurasi squirrelmail dilakukan 
dengan menjalankan skrip conf.pl:

\$/var/www/wemail/config/conf.pl

E. Installasi dan konfigurasi semua paket (dns server, web server, mail server)

Berikut ini tahapan-tahapan installasi dan konfigurasi semua paket :

1. Masukkan Dvd debian.8 dan ketikkan perintah sebagai berikut :

\#apt-get install bind9 dovecot-imapd dovecotcommon apache2 php5 postfix ssh nmap squirrelmail > enter

2. Selanjtnya akan muncul perintah konfigurasi lalu ketik $\mathbf{y}>$ enter

3. Kemudian tekan Ok dan pilih No Configuration

4. Kemudian ketikkan perintah seperti dibawah ini \#nmap localhost > enter

(fungsi nya untuk melihat paket-paket yang sudah terinstall)

5. Ketikkan perintah cd /etc/bind $>$ enter

6. Ketikkan perintah \#cp db.local nama anda $>$ misalnya : cp db.local basorudin

7. Ketikkan perintah \#nano nama anda > misalnya : nano basorudin Kemudian Edit konfigurasi seperti dibawah ini :

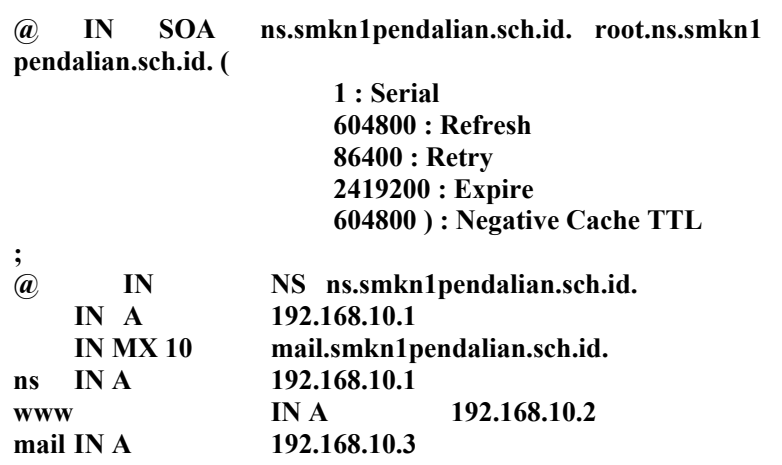

8. Setelah selesai save dengan cara $\mathbf{c t r l}+\mathbf{X}>\mathbf{y}$

9. Ketikkan perintah \#nano named.conf

10. Edit zone " 0 sebagai berikut : zone "smkn1pendalian.sch.id" \{ type master; file "/etc/bind/basorudin"; ;; zone "10.168.192.in-addr.arpa" \{

type master;

file "/

\};

11. Simpan konfigurasi diatas dan restart $\# /$ etc/init.d/bind9 restart

12. Lihat apakah Dns sudah jalan dan terhubung ke smkn1 pendalian, ketikkan perintah berikut ini \#nslookup smkn1pendalian.sch.id \#ping smkn1pendalian.sch.id

13. Uji dengan Mozila firefox, goggle chrome, boleh juga dengan yang lainnya apakah sudah jalan Dnsnya, ketikkan nama domain yang telah dibuat pastikan muncul tulisan it work !.

\#www.smkn1pendalian.sch.id

14. Selajutnya konfigurasi apache dan mailnya. \#nano /etc/apache2/sites-enabled/000-default

15. Paling atas tambahkan: ServerName smkn1pendalian.sch.id

16. Kemudian cari kata-kata Alias /doc/ “/usr/share/doc/" di bawahnya ketikkan setelah itu simpan

Alias /webmail/ “/usr/share/squirrelmail/"

17. Ketikkan perintah

\#nano /etc/dovecot/dovecot.conf

\#nano /etc/dovecot/dovecot.conf

18. Hilangkan tanda \# pada Mail_location =mbox: /mail: INBOX: /var/email\%u

19. Hilangkan tanda \# pada disable_plaint text_auth = yes, ganti dengan No dan simpan hasilnya

20. Ketikkan Perintah \#dpkg-reconfigure postfix

21. Kemudian tekan Ok $>$ Pilih Internet Sites, Pada system mail name $>$ isikan Debian $>$ Ok $>$ Ok

22. Kemudian edit alamatnya seperti berikut ini $>$ smkn1pendalian.sch.id,

mail.smkn1pendalian.sch.id, debian, localhost, localdomain, ,localhost

23. Selanjutnya tekan Ok $>$ Yes

24. Edit angka nya seperti berikut ini $>$ 192.168.10.0/24, 127.0.0.0/8 $>$ Ok $>$ Yes $>$ Ok $>$ Ok $>$ all $>$ Enter

25. Restart semua Konfigurasinya seperti perintah di bawah ini : 


\section{/etc/init.d/bind9 restart $>$ Enter \\ /etc/init.d/apache2 restart $>$ Enter \\ /etc/init.d/dovecot restart $>$ Enter \\ /etc/init.d/postfix restart $>$ Enter}

26. Sekarang silahkan tambahkan 2 user untuk email nya : Contoh :

1. adduser ali $>$ Enter

lalu isikan password : 123

enter terus hingga muncul pertanyaan lalu jawab $\mathbf{y}>$ Enter

2. adduser budi $>$ Enter

lalu isikan password : $\mathbf{1 2 3}$

enter terus hingga muncul pertanyaan lalu jawab $\mathbf{y}>$

Enter

\section{Pengujian}

\section{A. Tampilan akhir dan Proses Pengiriman Mail Server}

Pengiriman e-mail dilakukan dengan aplikasi Mozilla Firefox atau Google croom dan webmail SquirrelMail. Hasil pengujian pengiriman e-mail dapat dilihat pada Gambar 3.

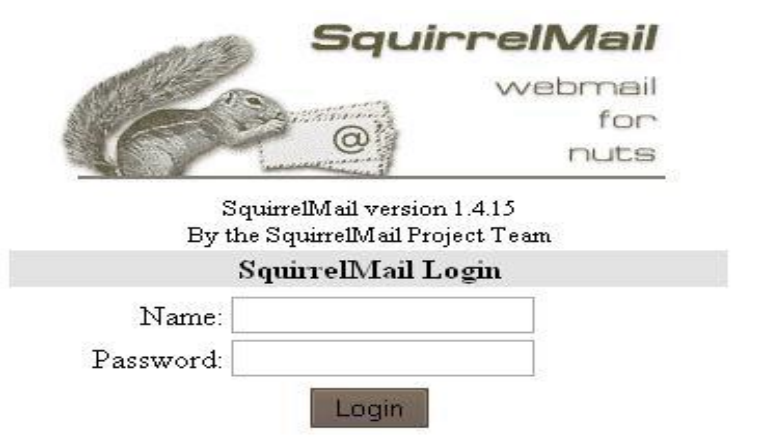

Gambar 3. Tampilan akhir dari Webmail

\section{B. Proses Pengiriman Mail Server}

Berikut ini adalah langkahlangkah proses pengiriman email :

1. Masukkan adduser nya $>$ contoh Nama ali password $123>$ Login

2. Kemudian klik Compose $>$ pada To isikan alamat email yang akan di tuju $>$ ketikkan $>$

budi@mail.smkn1pendalian.sch.id atau cukup ketikkan budi > pada Subject isikan Judul pesan > dibawahnya isikan kata-kata sesuai selera anda $>$ klik Send
3. Anda juga dapat mengirimkan sebuah File atau Dokument

4. Kemudian keluar $>$ klik Sigh Out $>$ lalu Click here to $\log$ back in $>$ masukkan adduser

kedua yaitu Nama budi password $123>$ Login $>$ lalu buka hasil kiriman dari ali tersebut.

\section{VI.PENUTUP}

\section{A. Kesimpulan}

Berdasarkan hasil perancangan dan implementasi mail server berbasis squirrelmail dapat disimpulkan beberapa hal sebagai berikut :

1. Perancangan dan implementasi mail server ini dibangun dengan menggunakan Debian.5 sebagai base operating system server.

2. Perancangan dan implementasi mail server ini dibangun dengan menggunakan dns server, web server dan mail server/squirrelmail, di konfigurasi menggunakan bantuan aplikasi virtualbox sebagai server.

3. Dengan adanya server di SMK N 1 Pendalian, semua e-mail dikelola oleh admin tanpa harus melakukan remote ke layanan hosting. Postfix adalah salah satu aplikasi mail gratis yang dibuat oleh Wietse Venema. Postfix dapat diintegrasikan dengan Dovecot agar client dapat membaca dan mengambil e-mail langsung dari server.

\section{B. Saran}

Untuk pengembangan penelitian selanjutnya maka di sini penulis menyarankan agar :

1. Menggunakan system operasi open source yang lain, misalnya ubuntu, caldera dan lain-lain atau dengan system operasi debian namun versi yang lebih tinggi, sehingga fasilitas pilihan juga lebih lengkap.

2. Mail server yang dibuat dan diimplementasikan ini masih bersifat privat dan offline, disarankan agar mengembangkan yang bersifat public dan online.

3. Disarankan bagi penulis lain untuk mengembangkan dengan motode lain sehingga menghasilkan output yang berbeda pula. 


\section{DAfTAR Pustaka}

Kusmaya, (2016). Implementasi Mail Server Menggunakan Postfix, Jurnal Informasi, Teknik Informatika, Fakultas Teknik Universitas Langlangbuana.

Heru Prasetiawan, (2016). Perancangan Mail Server Zimbra Menggunakan Teknologi Virtualisasi, Jurnal TAM (Technology Acceptance Model) Volume 7, Desember 2016, Universitas Budi Luhur Jakarta Selatan 12260.

Zainul Hakim dkk. (2015). Perancangan Mail Serverdengan Menggunakan Exchange ServerStudi Kasus di STMIK Bina Sarana Global, Jurnal Sisfotek Global, Universitas Budi Luhur.

Desmira, (2017). Rancang Bangun Mail Server Berbasis Squirrelmail Menggunakan Mta (Mail Transfer Agent) Pada Pt. Teras Inti Media, Jurnal PROSISKO Vol. 4 No. 2 September 2017. Program Studi Sistem Komputer - Universitas Serang Raya
Andika Saputra, (2012). Perancangan Dan Implementasi Mail Server Pada Cv. Sanjaya Anugerah Sejahtera (Isp Jogjaringan) Berbasis Open Source, Jurnal Dasi Issn: 1411-3201 Vol. 13 No. 2 Juni 2012.

Muhammad Dedy Haryanto, (2014). Analisis Dan Optimalisasi Jaringan Menggunakan Teknik Load Balancing (Studi Kasus : Jaringan Uad Kampus 3). Jurnal Sarjana Teknik Informatika eISSN: 2338-5197, Volume 2 Nomor 2, Juni 2014. Universitas Ahmad Dahlan.

Budi Harijanto, (2015). Desain Dan Analisis Kinerja Virtualisasi Server Menggunakan Proxmox Virtual Environtment. Jurnal Simantec, Vol. 5, No.1 Desember 2015.

Vredi Sanjaya,M.Akbar, (2016). Analisis Kinerja Virtualisas Server Menggunakan Proxmox Ve Pada Dishub Kominfo Sumatera Selatan. Universitas Bina Darma. 